\title{
Analysis on the Present Condition Differences between the Specialty- Education of Sino-American Construction Engineering Management \\ ${ }^{\mathrm{a}}$ Guo Hongying, ${ }^{\mathrm{b}}$ Kang Xiangping, ${ }^{\mathrm{c}}$ Ma Zhe
}

Department of Building Engineering, Henan University of Urban Construction Pingdingshan, Henan, China

\begin{abstract}
The paper, beginning from the course-system setting, the teacher-education measure, the student's Occupational Ethics, the practice ability, the communication-ability's cultivating and so on, makes an analysis of the differences between the specialty education of Sino-American Construction Engineering Management, points out the problems and shortcomings existing in present education of the specialty education of Project Management in our country, and puts forward some means and ways to solve the problem.
\end{abstract}

Index Terms: Construction Management; Project Management; course-system; cultivated scheme

(C) 2012 Published by MECS Publisher. Selection and/or peer review under responsibility of the International Conference on E-Business System and Education Technology

\section{Introduction}

Basing on the integration of the original specialty such as Construction Management, International project Management, Real Estate Management and so forth, China Project Management was set up by Ministry of Education in China in 1998. At present, over 200 universities offer the specialty in our country. For a few decades, with its scale's widening, it has developed very quickly. However, the teaching system has been in the exploration and perfection, and there is good distance between the arrangement of content and the real needs of the management posts of China construction industry. Presently, the competition mechanism of China construction has been complete and perfect, which has connected the international construction market. It is in great need for the internationalization of construction to examine the specialty education of China's Engineering Management from the international perspective, to promote the identification of the education and the talent internationally and as the result, to strengthen China construction enterprises' ability of taking part of the international competition. So it is significant to study the thoughts, the education teaching-pattern and means of the specialty education of foreign construction management represented by American. By which, we can use their experience to heighten the teaching-level of the major-China construction management and to improve the identification of the graduates in the working market. 


\section{THE ESSENCE OF AMERICAN CONSTRUCTION ENGINEER MANAGEMENT}

The education of Baccalaureate Degree and Associate Degree have been under the auditing of American Council for Construction Education (ACCE) being established in 1974 [1] and the valid is lasted for 6 years. Though ACCE tells the authorization are aiming at the construction specialties and not limits the scope of construction management majors specially but in fact, all the specialties passing the authorization are almost construction ones. From the standards of the authorization, it is aiming at the common construction management majors. China Project Management is a new specialty in our colleges and universities and was set up in 1998. In October 1998, the High Project Management Course-Specialty Guiding Committee was established by PRC Ministry of Construction, and makes the Project Management Cultivating Plan, the Teaching Program of the Platform Courses of Project Management and the Course-Teaching Program of Project Management Major. According to the Project Management Cultivating Plan, the specialty Project Management aims at the Construction Trade and cultivates the talents majoring in Construction Management. So the courses setting up in our country are equal to the construction management specialties in America. Generally, in the position of Project Management Specialty, it shows no difference between China and America $[2]$ 。

\section{The Present Condition Differences between the Specialty-Education of Sino-American Construction Engineering Management}

\section{1 The Setting of Course-system}

According to the Project Management Cultivating Plan making by PRC Ministry of Construction, the specialty of Project Management offers five course-directions as follows: Project Management, Operation and Management of Real Estate, Investment and Cost Management, International Project Management and Property Management. The course-system is basic courses + platform courses + directional courses. The platform courses belong to major basic courses including technique platform courses, economy platform courses, management platform courses and law platform courses. Statistics of the ratio of class hour to credit of the four platform courses coming from the five home universities' Project Management Specialty-besides Tsinghua University suggest that, technique platform course adds management platform courses, the average ratio of class hour to credit is $75.95 \%$, and the average ratio of class hour to credit of the project technique platform courses (architectural science\& Construction) in several American universities is almost 82.75\%.

Standards and Criteria for Accreditation of Postsecondary Construction Education Degree Programs of ACCE stipulate that the specialty of Construction Management should meet the need of general knowledge education and major education to offer the related courses which is necessary for supporting the subject. As the result, the standards ask to offer the five kinds courses such as Mathematics and Science, Mathematics and Science, Business and Management and Construction Science and Construction. [3] Among them, the highest average ratio of class hour to credit is that of the courses of Construction Science and Construction, and they are 42.41 and $43.4 \%$ [4] respectively. ACCE awards the education unit right to develop the course system, to award the degree's name and levels, and to identify the scores of students transferring from other schools, encourage the unit which has pass the authorization to evaluate the present course system frequently and develop the new one which can show the change trends of construction technique and management. The course system can be developing into a single specialty as well as a part which can be chosen by many majors, and that is similar with that of the five directions set up in Chinese Engineering Management.

\section{2 The Measure of the Cultivation of Teaching Stuff}

According to ACCE, the continued improving of teacher's ability is the necessary prerequisite to the valid teaching. So it asks for the education unit to take the evaluation of teachers as important as the teacher's experience and formal education background. What's more, within the colleges and universities policy, the administration personnel should encourage teachers to develop their major ability, for example, to spend the 
holiday on obtaining work experience, learning and studying, taking part in major groups, presenting major conference, seminar and so on. And the education unit should ensure all teachers the opportunity to develop their specialty. In our country, Project Management is a new specialty establishing in 1998, and in a short time, over 200 universities have offered the major. However, the teacher is in great need, and the excellent ones are very rare. So all the universities have no way to ensure the teacher to go out for further study, few teachers have taken part in social organization and consulting service, and it is impossible for the teacher to have the chance to develop their major. By investigating the teachers of Project Management courses, there are 1-2 professors in nearly 60\% Colleges and Universities of this specialty; 2-6 associate professors in nearly 68\% and 3-6 docent instructors in nearly 59\%. From above information, most Project Management Specialty in our country lack qualified teacher personnel, and from the aspects as title, education background and major ability, there is great distance between China and America.

\section{3 The Cultivation of Occupational Ethics}

The high education in China aims at cultivating the high-class major talent and management personal who is comprehensive development in moral, intelligence and sports, and can meet the need of socialism construction. So from the very beginning, the colleges and universities pays great attention to cultivate student's ideological politics and morality, but the courses provided for by the State, and generally, the content does not aim at special major. And many special trade's people, e.g. the construction administrator, what they are need in occupational ethics and major spirit has not brought into the line with the specialty plan. ACCE brings code of ethics into the compulsory course of general knowledge, and the credit will be at least 1 score. Moreover, code of ethics must mix into at least five construction courses or construction\& science courses. Grade Three has one compulsory course-Ethics in Construction in American Ball State University [5].And the course, from the contemporary practice to development of construction occupation, teaches modern construction industry ethics and specialty spirit, analyzes the present and future role of construction administrator from the international perspective, explain the principle and practice of trade spirit, the responsibility of society, district and environment, rules and regulations, behavior code and practice, law requirement, license etc., comment the establishment and framework of enterprise, and from the global aspect to analyze the influence of economy, market and the diversity of culture on construction management. Additionally, it specially tells the labor law relationship between worker and boss and the benefit of life-long learning. The quality of construction has direction influence on the safety of every people's body and property, but there are many problems in Chinese construction quality. The main cause lies in the incompleteness of related regulations and rules and surveillance system, and at the same time, the employers' common lack of the occupational ethics and specialty spirit also has great influence on it.

\section{4 The Cultivation of Practical Ability}

Because of taking teaching too much for granted but lacking teaching practice, students are short of vivid experience of solving problems, which hampers them from using theory to solve practical problems. By investigating statistics, "less than normal practical teaching contents" exist generally and sticking out clearly in construction engineering management specialty of china. Take the undergraduate education of construction engineering management specialty as an example, besides usual curriculum-design and graduate-design, there is little time for them to practice for graduation. ACCE demands it is that teachers, students and construction industry similar on-the-spot investigation, exchanges and cooperation in the form of lectures for students group should be recorded. Students should actively participate in related construction industry associations, learned societies etc., and also get work experience of the trade by taking part in activities such as practice, cooperation educational programs and so on. Although ACCE hasn't a clear demand on working time, generally, construction management majors of American University ask a student to work not less than 800 hours before graduation. And the educational institutions must establish consultative committee composing of representatives from the field of construction industry, and it must have a meeting within a year, actively gives suggestion to help educational units to revise and perfect the professional training program. 


\section{5 The Cultivating of Communication Ability}

ACCE claims that people and relationships are involved in construction process, and it is absolute necessary for engineering builder to have the oral, written and understanding ability. The standards place courses of oral and written communication on that of general knowledge education, demand the credit of oral and written communication more than 2, and both of them are formal and separate courses, total credits must be at least 8 . Besides separate courses, verbal, technical writing or business writing must be integrated into at least $33 \%$ of the construction and building science curriculum [6]. But the project management professional students in our school pay more attention to specialty theoretical study and design test, etc. Developing students' communication skills is largely ignored. In the Southeast University of Project Management Professional Training Program [7], capacities of the graduates have four, and the last is the expression, management, and public relations capacity, but in its training program, these courses are not included. Ministry of Construction's "Project Management Professional Training Program" and other key universities of project management professional training programs haven’t a clear communication skills training requirements for students.

\section{Suggestions and Countermeasures.}

\section{1 Positioning Subject Explicitly}

Subject positioning is important for professional development. Only according to accurate subject positioning and training objectives, developing targeted training programs, designing the curriculum system and determining the course content, school can foster the qualified personnel adapting the development of market economy. The positioning of our country engineering management subject should be: a subject that involves management problems, such as planning, organizing, resource allocation, command and control and so on in the engineering technology activity. Engineering management education in China should follow a marketdemand-oriented, emphasizing a practical road. On the basis of fully reflecting engineering management profession school characteristics, combining with their own advantages, national policies, market demand, Training units determine the training objectives.

\section{2 Strengthening Teaching Staff}

It is an urgent task currently to strengthen teacher education in engineering management professional education. Hire the staff of practical experience, highly theoretical level to participate in teaching activities, improve the teacher structure. Introduce the external experts with practical experience to conduct case studies teaching. Strengthen in-service training for teachers. Support teachers to participate in the domestic and international training courses and seminars. Encourage teachers to devote themselves to social appointments related to their teaching. Strengthen the practical awareness of teachers to improve their practical experience. Improve the knowledge structure of teachers. Establish access system for professional teachers of engineering management class, and at the same time, take the assessment mechanism for teachers. Promote teachers to research and improve teaching methods. Establish the evaluation and incentive mechanism of teachers.

\section{3 Adjusting Teaching Content}

Engineering management talent should have systems thinking, management and organizational skills, good oral and communication skills. Master engineering technical expertise, and have the ability of economic analysis, computer software application, and practical operation. In the curriculum, emphasize knowledge hierarchy integrity, coordination and balance, coordinate the ratio and proportion between engineering technology and management courses, and the ratio and proportion of theory and teaching practice. On the one hand, hang the engineering content and knowledge management together organically; the other hand, strengthen the engineering and practice teaching. At the same time, strengthen the education of the professional conduct and the spirit of profession to the students. Foster students the ability of good oral expression and social skills. 


\section{4 Strengthening Practical Teaching.}

Pay attention to teaching Practice. Establish training bases through such means as Cooperation among industry, universities and research institutes. Strengthen teachers' practice awareness and improve their practical experience. Encourage students to participate in various competitions, entrepreneurship design competition, and subject study. Strengthen the application of modern information technology in engineering management. Make the best of modern teaching methods, such as: application of some project management software, to establish some laboratories to conduct engineering management simulation. Connect Curriculum design and graduate design organically, and detail assessment criteria. Suggest increasing the "whole process of project management simulation" to dissertation stage. Increase Credit Hours and course content; establish appraisal standards of practice Course. Implement case teaching, establish case base. Strengthen the theoretical study after having practiced. Strengthen the teaching link of engineering and practice. Increase case Teaching, simulation training or on-site teaching.

\section{References}

[1] American Council for Construction Education [EB/OL[009-09-13] .http://www.acce-hq.org/.

[2] Wang,Yingluo, “Wang Nengmin. Status andDevelopment of Engineering Management”, Engineering Science, pp. 11-17, June 2006. (in Chinese)

[3] Li, Xingsu. "Reflection on Undergraduate teaching and training program setting of Engineering Management”, Project Management Technology, pp. 68-71, June,2008. （in Chinese）

[4] University of Cincinnati. College of Applied Science [EB/OL] [2008-03-19]. http://www.uc.edu/bulletins/cas.pdf.

[5] Ball State University. Syllabus of Ethics in Construction [EB/OL][2009-09-13]. http://www.bsu.edu/itech/course/0, 2472, 230933-15402-ITCST-310, 00.html.

[6] Purdue University. Building Construction Management program [EB/OL][2009-09-13]. http://www.tech.purdue.edu/Bcm/academics/undergraduate/bcm_pos.cfm.

[7] Southeast University. Southeast University, 2005 Project Management Undergraduate program Training Program[EB/OL] [2009-09-13]. http://61.155.9.198/2008Contact/Choice/HandBook/UploadFiles/01.pdf. (in Chinese) 